\title{
GEOLOGICAL STUDIES IN AN AREA OF INDUCED SEISMICITY \\ AT MONTICELLO RESERVOIR, SOUTH CAROLINA
}

\author{
Donald T. Secor, Jr. \\ Department of Geology \\ University of South Carolina \\ Columbia, South Carolina 29208
}

USGS CONTRACT NO. 14-08-0001-19124

Supported by the EARTHQUAKE HAZARDS REDUCTION PROGRAM

OPEN-FILE NO.81-380

U.S. Geological Survey

OPEN FILE REPORT

This report was prepared under contract to the U.S. Geological Survey and has not been reviewed for conformity with USGS editorial standards herein do not necessarily represent those of the USGS. Any use of trade names is for descriptive purposes only and does not imply endorsement by the USGS. 


\section{GEOLOGICAL STUDIES IN AN AREA OF INDUCED SEISMICITY \\ AT MONTICELLO RESERVOIR, SOUTH CAROLINA}

BY

Donald T. Secor, Jr., Principal Investigator

Department of Geology

University of South Carolina

September 30,1980

Sponsored by the U.S. Geological Survey, Contract No. 14-08-0001-19124

The views and conclusions contained in this document are those of the author and should not be interpreted as necessarily representing the official policies, either expressed or implied, of the U.S. Government. 


\section{ABSTRACT .}

This is the first technical report of a two-year study of the geology of the Lake Monticello region, South Carolina. This work was undertaken in order to determine the geological factors responsible for the induced seismic activity at Lake Monticello.

During the period $3 / 1 / 80-9 / 1 / 80$ we 1) conducted geological field mapping in the Chapin, Little Mountain, and Jenkinsville quadrangles, 2) measured a detailed magnetic profile across the Chapin and Little Mountain quadrangles, and 3 ) measured the orientations of approximately .4200 joint fractures at 39 different stations in the Chapin, Little Mountain, Jenkinsville, and Pomaria quadrangles.

We have distinguished ten distinctive lithologic units in the rocks of the study area, and preliminary geologic maps showing the distribution of these units are presented for the Chapin, Little Mountain and portions of the Jenkinsville quadrangles. The rocks of the study area were strongly deformed during the Early to Mid Paleozoic. As a result of this deformation, many of the lithologic units contain a strong metamorphic foliation, and were folded into a tight syncline, the axis of which passes through the southern parts of the Chapin and Little Mountain quadrangles. During the Late Paleozoic, the rocks in the study area were again deformed during one or more episodes of flexural folding and a series of large adamellite plutons were emplaced in the northern parts of the study area. The latest Paleozoic and Mesozoic history of the area was characterized by brittle faulting and by the emplacement of northwest trending diabase dikes. During this period it appears that a north trending fault (the Wateree Creek fault) developed in the central part of the Chapin quadrangle. 
The latest movement on the Wateree Creek fault may postdate the emplacement of the diabase dikes of Jurassic (?) age. The Wateree Creek fault trends in the general direction of Lake Monticello and may be an important factor in the induced seismic activity at Lake Monticello.

Additional geological studies are being conducted in an attempt to further document the extent and geological history of the Wateree Creek fault.

It is emphasized that the conclusions presented here are tentative and subject to change as the work progresses. 
TABLE OF CONTENTS

Page

ABSTRACT .........................

LIST OF FIGURES ....................... iv

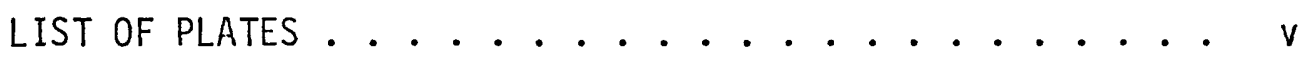

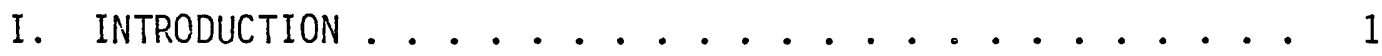

II. REGIONAL GEOLOGY .............. 5

II.1 Carolina Slate Belt........... 5

II.2 The Charlotte Belt .......... 10

III. FIELD MAPPING ....................... 11

III.1 Introduction . . . . . . . . . . . 11

III.2 Carolina Slate Belt Stratigraphic Units . . . . . 13

III.3 Charlotte Belt Stratigraphic Units . . . . . 15

III.4 Igneous Rccks . . . . . . . . . . . 17

III.5 Structurai Geology . . . . . . . . 18

III.6 The Wateree Creek Fault . . . . . . . 20

III.7 Summers Branch Fault . . . . . . . . . 23

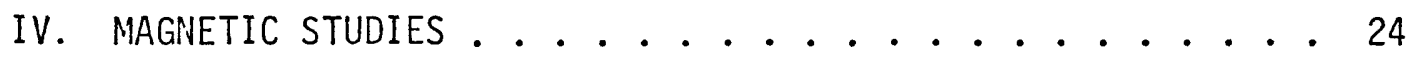

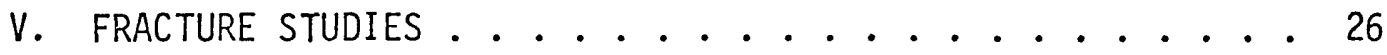

VI. SUMMARY DISCUSSION . . . . . . . . . . . . 28

VII. REFERENCES CITED ................. 30 


\section{LIST OF FIGURES}

Figure

Page

1 Index map to the study area around Lake Monticello,

South Carolina................. 2

2 Seismic activity associated with impoundment of

Monticello Reservoir.............. 3

3 Generalized geological map of the southern Appalachians. Modified from Williams (1978) . . . . . . . . 6

4 Generalized geological map of the Carolina slate belt in west-central South Carolina . . . . . . . . . 7

5 Legend for symbols used on Plates I, II, and III . . . 12

6 Aeromagnetic map of the Chapin quadrangle (U.S.G.S., 1978), showing the 1ciation of the Wateree Creek fault . 21 


\section{LIST OF PLATES.}

Plate

I

II

III

IV

VI

VII

VIII

IX
Geologic map of the Chapin quadrangle, by David Simpson.

Geologic map of the Little Mountain quadrangle, by Larry Peck.

Geologic map of a portion of the Jenkinsville quadrangle, by William Smith.

Magnetic profile across the northern part of the Chapin quadrangle.

Magnetic profile across the Little Mountain quadrangle.

Results of fracture studies in the Chapin quadrangle by Sarah Logan.

Results of fracture studies in the Little Mountain quadrangle by Sarah Logan.

Results of fracture studies in the Jenkinsville quadrangle by Sarah Logan.

Results of fracture studies in the Pomaria quadrangle by Sarah Logan. 


\section{INTRODUCTION.}

This is the first technical report of what is intended to be a twoyear study (3/1/80-2/28/82) of the geology of the Lake Monticello region, South Carolina (Fig. 1).

Lake Monticello is a hydroelectric pump storage reservoir, built in conjunction with the V. C. Summer nuclear station in Fairfield County, South Carolina, by the South Carolina Electric and Gas Company. Lake Monticello, covering $17 \times 10^{6} \mathrm{~m}^{2}$ and having a storage volume of $307 \times 10^{6}$ $\mathrm{m}^{3}$, was impounded on December 3, 1977, and full pond was attained February 8, 1978. A marked increase in the local seismic activity became evident about three weeks after the initiation of filling of the reservoir (Fig. 2; Talwani and others, 1978). This increased level of seismic activity has continued intermittently to the present. Lake Monticello is one of the most thoroughly documented cases of induced seismicity in the United States (Duc and others, 1978; Talwani and others, 1978; Talwani, 1979; Talwani and others, 1980).

The U.S. Geological Survey, the National Science Foundation, and the South Carolina Electric and Gas Company are supporting an intense research effort to understand the causes and controls of the seismic activity at Lake Monticello. It is hoped that this research will yield information that may ultimately be useful in the prediction and/or control of natural earthquakes. Moreover, this research may lead to a better understanding of the seismic risk in the densely populated Appalachian Piedmont Province. The interpretation of the geophysical information from the Lake Monticello area has been hampered by a lack of information on the geology of the region surrounding the reservoir. The studies described here were under- 


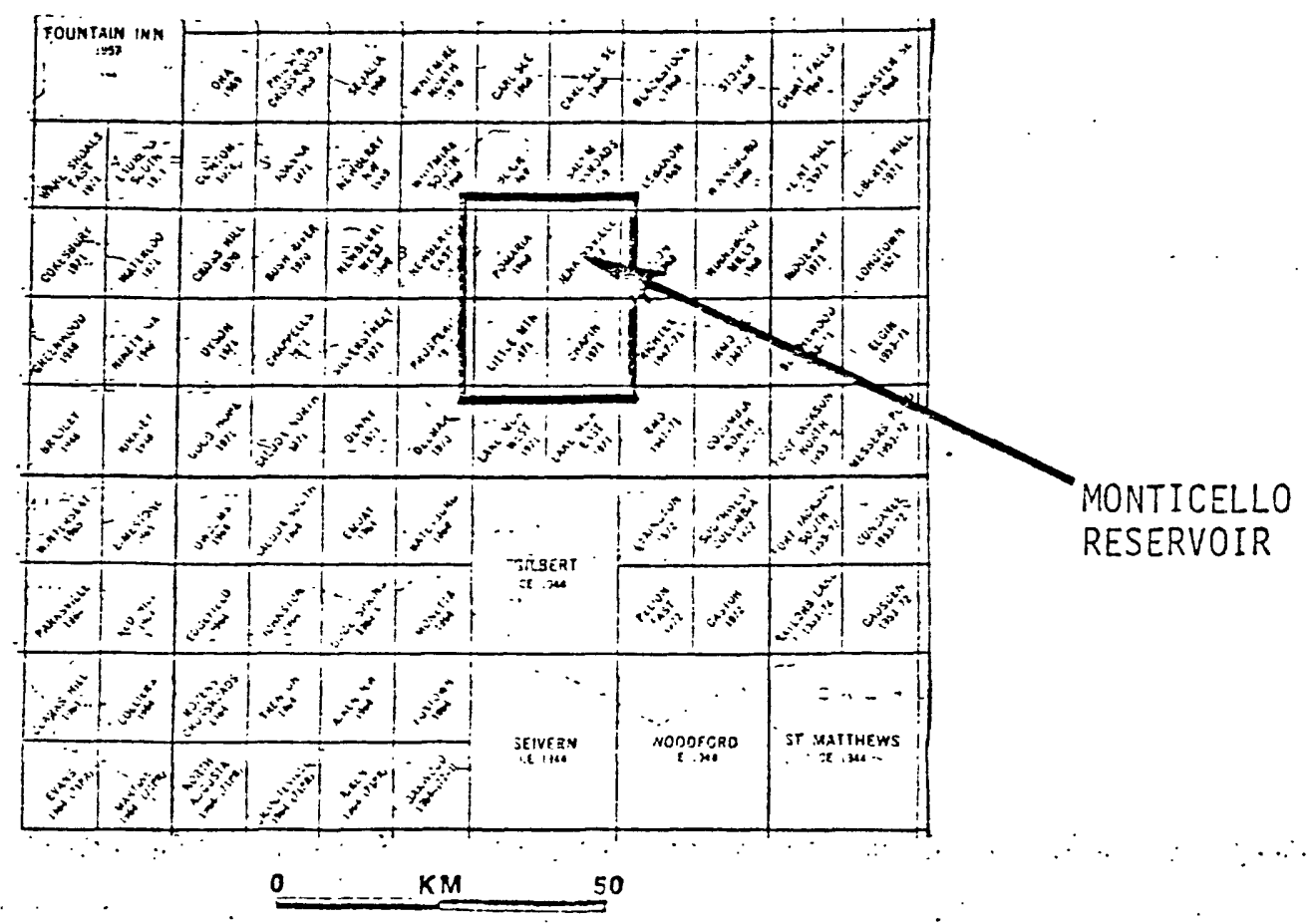

Modified from U. S. Geological Survey Index to Topographic Maps of South Carolina, 1978.

Figure 1. Index map to the study area around Lake Monticello, South Carolina. 


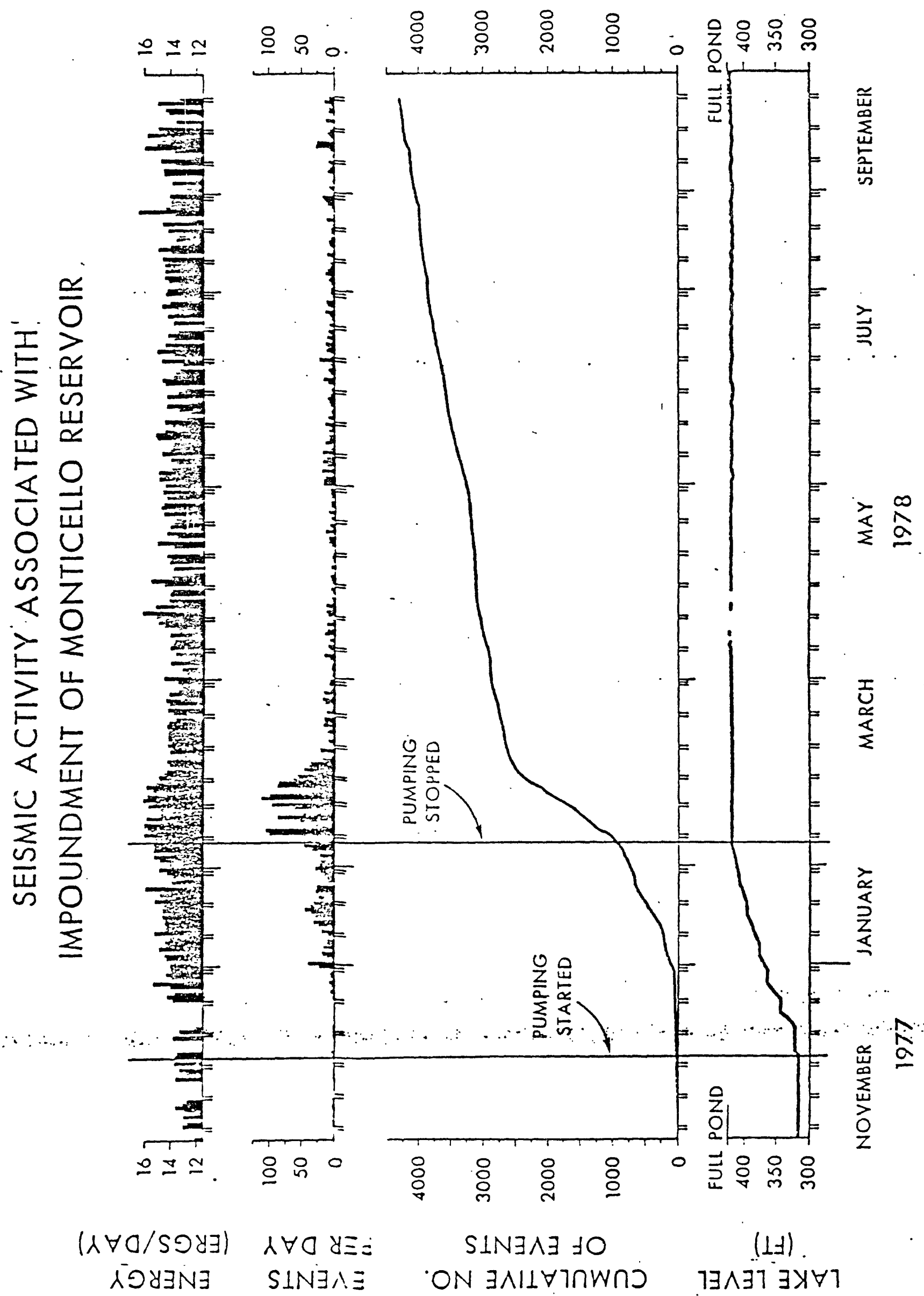

Seismic activity associated with the impoundment of Monticello Reservoir 
taken in order to provide the requisite geological information.

The seismic activity at Monticello Reservoir has brought into focus several fundamentaliy important geological questions:

1. Is the induced seismic activity fortuitous, resulting from the accidental coincidence of the reservoir with a local area of critically stressed rock and perhaps controlled by some local lithologic or structural inhomogeneity in the crystalline rocks beneath the reservoir?- or,

2. are the crystalline rocks in the southeastern Piedmont generally in a near-critical state of stress, perhaps resulting from the combination of a regional stress system with the effects of long-continued erosion, so that induced seismic activity will occur anywhere in this region that large reservoirs are constructed?

3. Is there danger that a damaging earthquake could eventualiy occur at Monticello Reservoir, perhaps along a major pre-existing, throughgoing fracture, or, are the rocks beneath Monticello Reservoir relatively intact so that the strain energy will be gradually released by slip along the innumerable short joints and small faults that are known to penetrate the rocks in this region (Dames and Moore, 1974, 1975)?

4. Is it possible that the metamorphic foliation or certain sets of joints or small faults are favorabiy oriented with respect to the stresses in the rock, and are reactivated by the small changes in stress and/or pore pressure resulting from the filling of the reservoir? 
In order to answer these questions, the following program of geological studies were undertaken:

1) Detailed field mapping of the Chapin, Little Mountain, Jenkinsville, and Pomaria 7 1/2 minute quadrangles in a corridor extending north from the Carolina slate belt out into the Charlotte belt around Monticello Reservoir.

2) Detailed mapping of swarms of northwest trending Mesozoic diabase dikes by means of a magnetometer survey.

3) Detailed fracture orientation studies at forty sites in the corridor where extensive outcrop is available.

\section{REGIONAL GEOLOGY}

The regional geology of this portion of the Appalachian Piedmont province has recently been extensively reviewed (Secor and Snoke, 1978; Snoke and others, 1980). The South Carolina Piedmont contains a number of northeast trending tectonic-metamorphic belts characterized by distinctive lithologies and metamorphism. The present study area is located a thwart the boundary between the Carolina slate belt and the Charlotte belt (Fig. 3).

\section{II.I Carolina Slate Belt}

The Carolina slate belt is a sequence of greenschist facies metavolcanic and metasedimentary rocks that extends along the Fall Line from Virginia to Georgia. In South Carolina and eastern Georgia the slate belt contains two terranes characterized by felsic metavolcanic rocks. These are flanked and separated by terranes of metasedimentary rocks (Fig. 4). The stratigraphic relationships between the terranes are controversial 


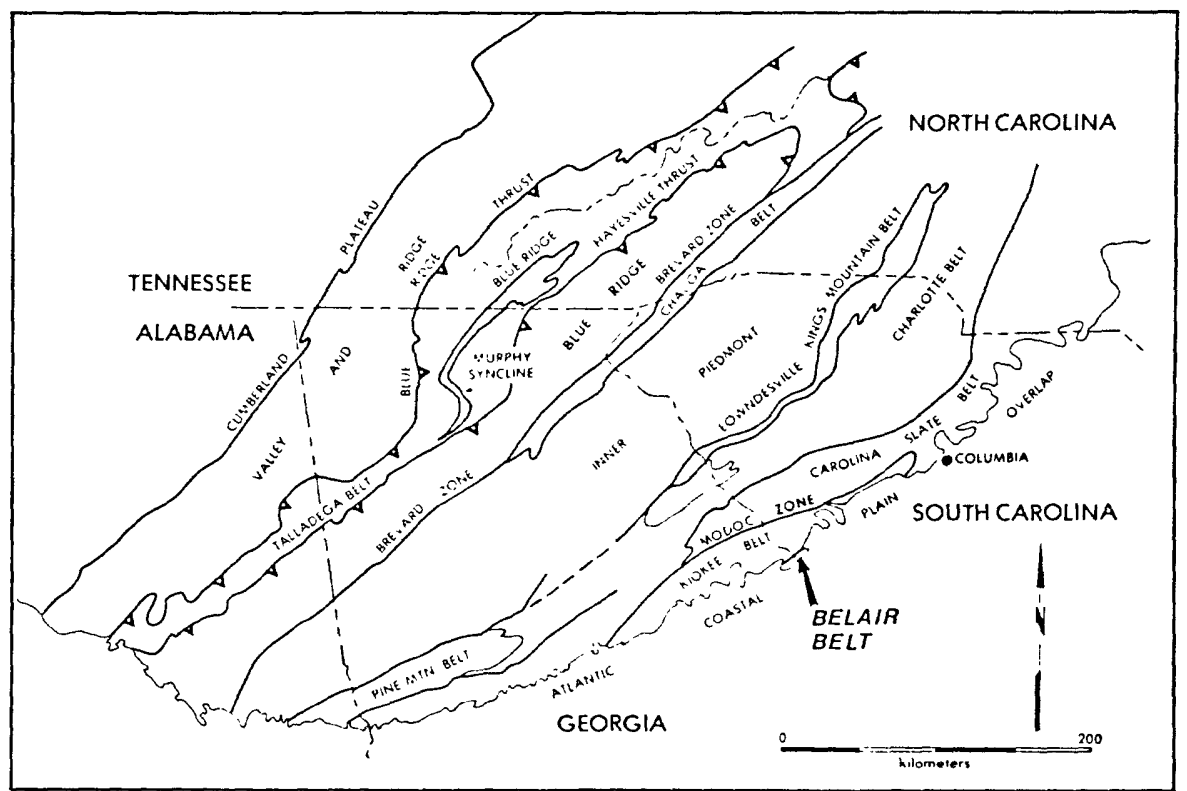

Figure 3. Generalized geological map of the southern Appalachians. Modified from Williams (1978). 


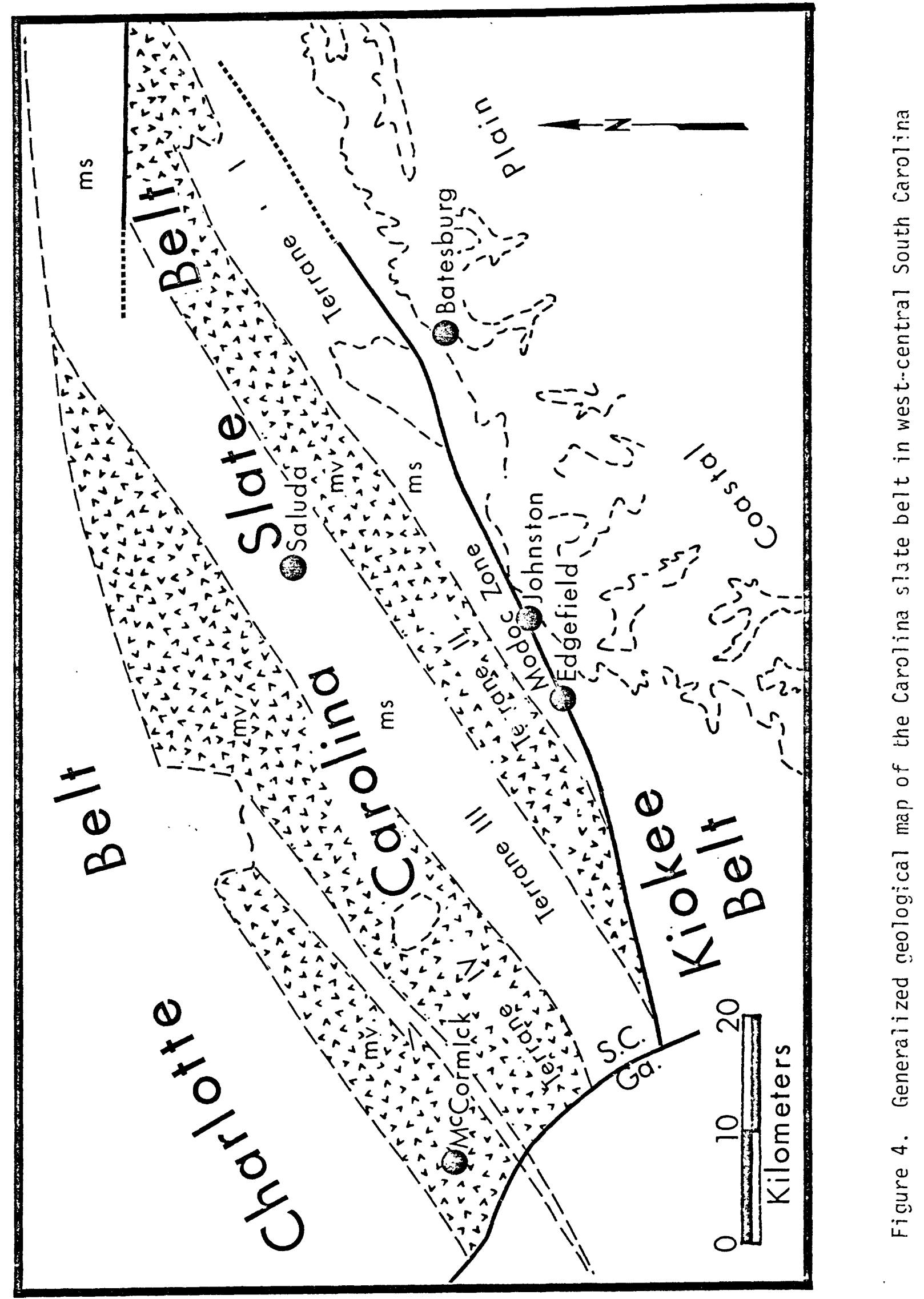


and uncertain (compare: Secor and Wagener, 1968; Danie1s, 1974; Carpenter, 1976; Howell and Pirkle, 1976; Pirkle, 1977, 1978; Secor and Snoke, 1978). The Carolina slate belt is commonly interpreted to have accumulated in an island-arc environment, al though there is uncertainty whether the arc was founded on oceanic or continental crust (Butler and Ragland, 1969; Whitney and others, 1978). Radiometric age determinations on felsic metavolcanic rocks from the Carolina slate belt (Hills and Butler, 1969; Fullagar, 1971; Glover and Sinha, 1973; Butler and Fullagar, 1975; Black and Fullagar, 1976; Seiders and Wright, 1977; Wright and Seiders, 1977; Black, 1978; Carpenter and others, 1978) indicate that the arc was active during the Late Precambrian and Cambrian, as do fossil remains that have been found in a few places (St. Jean, 1973; Cloud and others, 1976; Maher, 1978, 1980 in press). Petrologic studies indicate that the felsic metavolcanic rocks in the slate belt have an unusually low potassium content and may have been derived from tonalitic or trondhjemitic magmas.

Detailed structural studies in combination with geochronological studies indicate that the Carolina slate belt has been affected by at least two major periods of penetrative deformation. The first of these $\left(D_{1}\right)$ was an episode of tight to isoclinal folding and greenschist facies metamorphism that resulted in the development of a penetrative slaty cleavage. The age of the $D_{1}$ deformation is controversial (Seiders and Wright, 1977; Briggs and others, 1978; Kish and Fullagar, 1979), but $D_{1}$ definitely preceded the emplacement of a 325-265 m.y. suite of granite plutons in the slate and Charlotte belts (Fullagar and Butler, 1979). The second major period of deformation is characterized by folding and amphibolite facies regional metamorphism that is mainly manifested along the southeastern edge of the Carolina slate belt adjacent to the Atlantic Coastal Plain 
(Secor and Snoke, 1978; Snoke and others, 1980 in press). At least three distinct sub-episodes of deformation cin be recognized along the southeastern edge of the slate belt $\left(D_{2}, D_{3}, D_{4}\right)$. The effects of $D_{2}$ folding extend well out into the Carolina slate belt and may be present in the present study area. The effects of $D_{3}$ and $D_{4}$ seem to be restricted to the southeastern edge of the Carolina slate belt immediately adjacent to the Kiokee belt (Fig. 3). Geochronological studies indicate that $D_{2}, D_{3}$ and $D_{4}$ occurred during the period 315-265 m.y. (Kish and others, 1978).

Geophysical studies (Cook and others, 1979; Harris and Bayer, 1979) have indicated that a major sub-horizontal interface underlies most of the Piedmont and Coastal Plain at a depth of 5-15 km. This is interpreted to indicate that much of the Piedmont is allochthonous. The northwestward directed overthrusting is probably in part related to the 315-265 m.y. Carboniferous deformational episode, al though some overthrusting could hav. also occurred in the Mid to Early Paleozoic.

The Mesozoic history of the Piedmont is characterized by block faulting and the development of sediment filled fault troughs. These fault troughs have been almost completely removed from the South Carolina Piedmont by erosion, but the related silicified fault zones have been recognized in many places. These Mesozoic faults are commonly associated with quartzfilled extension fractures, and zeolite mineralization accompanies fracturing in many places (Conley and Drummond, 1964; Privett, 1973a, 1973b, 1974a, 1974b, 1977; Brown and Gilbert, 1977; Butler, 1977; Wagener, 1977; Snipes and others, 1979). Numerous northwest-trending diabase dikes were also intruded during the Mesozoic.

The Cenozoic history of the Piedmont is generally characterized by erosion and tectonic stability, al though north trending faults that displace 
Tertiary strata have been recognized in the vicinity of Augusta, Georgia (O'Connor and Prowe11, 1976; Prowell and O'Connor, 1978), and these may extend into west-central South Carolina.

\section{II.2 The Charlotte Belt}

The Charlotte belt is a heterogeneous group of igneous and amphibolite facies metamorphic rocks that outcrop in a broad band trending northeast across the central part of the South Carolina Piedmont. The general geologic history of the Charlotte belt is similar to that of the adjacent Carolina slate belt, but intrusive igneous and metaigneous rocks are much more abundant in the Charlotte belt than in the slate belt. The oldest rocks in the Charlotte belt are amphibolite, biotite gneiss, and hornblende gneiss that are thought to have been derived from volcanic, volcaniclastic, and/or sedimentary protoliths. These are intruded by voluminous prekinematic, synkinematic, and postkinematic plutonic rocks of diverse composition. The oldest group of plutons (ca \pm 550 m.y.; Fullagar, 1971; Gilbert and Schaeffer, 1979) usually carry a gneissic deformational fabric al though the intensity of the fabric varies widely. The composition of this oldest group of plutons varies between gabbro, diorite, tonalite, trondhjemite, and adamellite, and they have been interpreted as epizonal intrusions genetically related to the volcanic and volcaniclastic rocks of the Carolina slate belt (Fullagar, 1971; Weisenfluh and Snoke, 1978). A younger group of late synkinematic granite, adamellite, syenite, diorite, and gabbro plutons also intrude the Charlotte belt. These are best documented in North Carolina (Butler and Fullagar, 1978) al though the Lowrys and Bald Rock plutons in South Carolina also belong to this group. Finally, 
both the Charlotte belt and the Carolina slate belt are intruded by the postkinematic Carboniferous plutons (Fullagar and Butler, 1979) of granitic composition. In the region the present study, the Newberry and the Winnsboro plutons belong to this postkinematic group.

\section{FIELD MAPPING}

\section{III.1 Introduction.}

Most of the study area is contained in the Chapin, Little Mountain, Jenkinsville, and Pomaria 7 1/2 minute U.S.G.S. quadrangle maps. Primary responsibility for mapping these quadrangles has been undertaken by the following M.S. candidates at the University of South Carolina: David Simpson (Chapin), Lawrence S. Peck (Little Mountain), William A. Smith (Jenkinsville), and David M. Pitcher (Pomaria). Geological studies in the Chapin and Little Mountain quadrangles have been underway since the initiation of this project in March, 1980. Studies in the Jenkinsville and Pomaria quadrangles were initiated on $6 / 15 / 80$ and $8 / 15 / 80$ respectively. Preliminary versions of the geological maps for Chapin, Little Mountain, and Jenkinsville are presented in Plates I, II, and III respectively (see Figure 5 for the Legend corresponding to these maps). It is anticipated that field studies in the Chapin and Little Mountain quadrangles will be completed by $3 / 1 / 81$, and field studies in Jenkinsville and Pomaria will be completed by $3 / 1 / 82$.

Ten $1 i$ thologic units have been recognized in the Chapin, Little Mountain, and Jenkinsville quadrangles. Six of these are metasedimentary or metavolcanic sequences, and the remaining four are igneous or metaigneous rocks. The relative ages of some of the units can be inferred from 
CAROLINA SLATE BELT

Emw Evenly laminated to massive mudstone and wacke.

Eg Amygdaloidal greenstone.

Edf Volcanic debris flow sequence.

Efq Felsic ashflow tuff, feldspathic quartzite, and impure silts tone.

CHARLOTTE BELT

Eggn Granitic orthogneiss

Esp Biotite schist and biotite paragneiss.

Ea Amphibolite

INTRUSIVE IGNEOUS ROCKS

Ca Adamellite

$\mathrm{Cg} \quad$ Gabbro

Jd Diabase

30

Strike and dip of bedding or compositional layering (So).

75) Strike and dip of $S_{1}$ foliation.

$\rightarrow 10 \quad$ Trend and inclination of $L_{1}$ and $L_{0 \times 1}$

- - Stratigraphic or intrusive contact.

$-\infty-$ Fault

Figure 5. Legend for symbols used on Plates I, II, and III. 
structural relationships. The lithologic units in the Carolina slate belt are described separately from those in the Charlotte belt. It is possible that some of the metasedimentary or metavolcanic rok... units in the Charlotte belt are correlative with those in the Carolina siati belt. However, correlations between the slate and Charlotte bel ts could best be proven by tracing map units from one into the other, and regional geological studies have not yet progressed to the point where this is msible.

\section{III.2 Carolina Slate Belt Stratigraphic Units}

The oldest stratigraphic unit present in the Carolina slate belt is a sequence of interlayered felsic ashflow tuff, feldspathic quartzite, and impure silts tone $\left(E f_{q}\right)$. This unit occurs along the northern edge of the Carolina slate belt adjacent to the Charlotte belt. A northeast trending band of this unit, $0.5-2.0 \mathrm{~km}$. wide, extends across the central parts of the Little Mountain and Chapin quadrangles. The quartzites in this unit are particularly well developed on and adjacent to Little Mountain. We tentatively interpret the quartz-rich rocks in the Little Mountain region to have originated from an episode of volcanic-related hydrothermal silicification that is thought to have occurred prior to $D_{1}$ time. The rocks in this unit are commonly highly strained and recrystallized, and it is sometimes difficult to differentiate between felsic ashflow tuff and feldspathic quartzite in the field. In a few places the quartzites seem to contain relic flaser bedding and are interpreted to have originated as sedimentary quartzites. The felsic tuff-quartzite-siltstone sequence is probably partly coextensive with the terrane IV volcanic sequence which has been mapped along the northern edge of the slate belt in western South 
Carolina (Fig. 4). This unit also resembles. the Persimmon Fork Formation which outcrops extensively in terrane II in central and western South Carolina (Secor and Snoke, 1978).

A thick volcanic debris flow sequence ( $\epsilon$ df) outcrops extensively in the central and southern parts of the Little Mountain and Chapin quadrangles. This is interpreted to overlie the felsic ashflow tuff-feldspathic quartzi te-impure siltstone unit described above. The individual flow units in the debris flow sequence are typically several meters thick and consist of a muddy matrix containing numerous clasts of intermediate to felsic volcanic tuff and volcanic rock fragments. The clasts are typically a few centimeters in diameter and are variably flattened in the plane of $S_{1}$ foliation. Larger rounded volcanic rock fragments, $10-40 \mathrm{~cm}$. in diameter, are also common. Flattened clasts of graphitic muds tone are found in the debris flow sequence in most places. Small well rounded quartzite pebbles are an occasional minor component. Because of the predominately volcanic nature of the clasts, most previous studies (cf. Clark 1969) have characterized this unit as volcanic tuff. However the presence of some non-volcanic clasts suggests debris flow deposition. This debris flow unit is also coextensive with the terrane IV volcanic sequence (Fig. 4).

The youngest stratigraphic unit in the Carolina slate belt in this region is a sequence of evenly laminated to massive muds tone and wacke $\left(\epsilon_{\mathrm{m} \mathrm{w}}\right)$. This unit outcrops in a northeast trending band, $2-4 \mathrm{~km}$. wide in the southern parts of the Chapin and Little Mountain quadrangles. This unit is identical with metasedimentary terrane III, which is of widespread extent in the slate belt of South Carolina (Fig. 4). Graded layers of 
mudstone and/or wacke $0.5-3.0 \mathrm{~m}$. thick comprise the bulk of this unit. These layers are commonly separated by sequences of thin-bedded evenly laminated mudstone containing graded varve-like layers $0.1-3.0 \mathrm{~cm}$. thick This unit is interpreted as a turbidite sequence which accumulated in a quiet depositional basin below the influence of waves and tidal currents The mudstone and wacke unit is interpreted to occupy the core of a major. $D_{1}$ synclinorium, and grades down section into the thick volcanic debris flow sequence. In the eastern part of the Chapin quadrangle the muds tone and wacke unit contains a distinctive amygdaloidal greenstone $0-100 \mathrm{~m}$. thick at its base $\left(\hat{\varepsilon}_{g}\right)$.

\section{III.3 Charlotte Belt Stratigraphic Units}

The Charlotte belt is characterized by an abundance of felsic metaigneous rocks $\left(\epsilon_{g g n}\right)$; but it also contains a metavolcanic amphibolite unit $\left(\epsilon_{a}\right)$ and a metasedimentary biotite schist and biotite paragneiss unit $\left(\epsilon_{s p}\right)$. The metaigneous rocks clearly intrude the amphibolite, paragneiss, and schist and are therefore younger. The relative ages of the metavolcanic and metasedimentary rocks are not known.

The amphibolite unit outcrops in the northern part of the Little Mountain and Chapin quadrangles and in the Jenkinsville quadrangle. It is interpreted to be a mafic metavolcanic rock because it is interlayered with biotite schist and biotite paragneiss and locally grades into these rocks. However the amphibolite unit has undergone extensive metamorphic recrystallization, and original volcanic textures have not been recognized. The amphibolite unit may correlate with the amygdaloidal greenstone unit in the Carolina slate belt in the Chapin (this report) and Richtex 
quadrangles (Secor and Wagener, 1968). Alternatively, it may represent a mafic basement terrane upon which the slate belt island-arc was constructed.

The biotite schist and biotite paragneiss unit outcrops in the northern part of the Little Mountain and Chapin quadrangles. This unit has also undergone extensive metamorphic recrystallization and relic sedimentary or volcanic textures or structures have not been recognized. This unit may correlate with the volcanic debris flow $\left(\epsilon_{d f}\right)$ unit or with the eventy laminated to massive mudstone and wacke $\left(\epsilon_{\mathrm{mw}}\right)$ units in the Carolina slate belt. Alternatively, the biotite schist and biotite paragneiss unit may be older than any of the stratigraphic units in the Carolina slate belt.

Several extensive sheets of stratiform granitic orthogneiss $\left(\epsilon_{g g n}\right)$ intrude the Charlotte belt in the northern parts of the Little Mountain and Chapin quadrangles. Eventually it will be possible to subdivide this unit into a number of major compositional varieties; however, the petrographic work necessary for this subdivision is still in progress. A strongly deformed meta-quartz-feldspar porphyry occurs in the Charlotte belt immediately north of the border with the slate belt. These intrusive porphyries are very leucocratic and are practically devoid of potash feldspar. We interpret these porphyries to originally have.been emplaced as a series of epizonal trondhjemite dikes and/or sills that may be genetically related to the felsic volcanic rocks of similar composition in the Carolina slate belt. To the north, the deformed trondhjemitic rocks become coarser grained and less obviously porphyritic, suggesting that the metaigneous rocks in the interior of the Charlotte belt were originally emplaced at greater depths than the metaigneous rocks adjacent 
to the Carolina slate belt. A weakly deformed leucocratic granitic gneiss containing abundant potash feldspar is present in the vicinity of the clay pit in the west-central part of the Little Mountain quadrangle, immediately north of the Carolina slate belt. At present we are not able to separately distinguish this unit from the meta-trondhjemi te, although it probably is a late-synkinematic granite entirely unrelated to the trondhjemite.

\section{III.4 Igneous Rocks}

Several large postkinematic plutons of adamellite $\left(C_{a}\right)$ have been emplaced into the Charlotte belt in the Jenkinsville and Pomaria quadrangles and surrounding region (Wagener, 1970, 1977a; Dames and Moore, 1974; Bourland and Farrar, 1980). In the Jenkinsville quadrangle these plutonic rocks are typically a sparsely porphyritic, light gray, fine grained adamellite admixed with numerous amphibolitic xenoliths. In some places the xenoliths are extremely abundant constituting more than $50 \%$ of the rock. Large enclaves of country rock sometimes occur within the postkinematic plutons, and the country rock immediately outside the plutons is an injection migmatite in many places. The postkinematic adamellite in the Jenkinsville quadrangle closely resembles the rock found in the nearby Rion and Newberry plutons (Wagener, 1977a).

Two small pluglike masses of gabbro have been emplaced along the axis of a $D_{1}$ syncline in the southwestern part of the Little Mountain quadrangle. The aureole of contact metamorphism surrounding these bodies in the laminated to massive mudstone and wacke unit appears to overprint the $S_{1}$ foliation, and so the gabbro was probably emplaced in the Mid to Late Paleozoic. 
The youngest rocks in the study area are a series of olivine diabase dikes ( $u d$ ) of Jurassic (?) age (DeBoer, 1967). These trend approximately $\mathrm{N} 25^{\circ} \mathrm{W}$, are steeply dipping to vertical, and are up to 10 meters thick. The diabase dikes are difficult to trace by conventional field mapping techniques because they are susceptible to chemical weathering and outcrop very rarely. However the diabase dikes are extremely magnetic and can be easily traced with a proton precession magnetometer. The dikes often have magnetic anomalies of several hundred gammas. In the present study it is important to establish the precise locations of the diabase dikes in order to determine if they have been displaced by north or northeast trending faults. For this reason we have undertaken to measure several magnetic profiles across the study area. These magnetic studies, and the locations of the dikes discovered to date are described in a later section.

\section{III.5 Structural Geology}

The oldest recognizable deformation episode $\left(D_{1}\right)$ in the study area was a period of folding, intense penetrative strain and greenschist facies (slate belt) to amphibolite facies (Charlotte belt) regional metamorphism. This deformation produced a prominent metamorphic foliation that is the dominant fabric element in both the slate and Charlotte belts. In most places the $S_{1}$ foliation contains a strong subhorizontal elongation lineation $\left(L_{1}\right)$. The lapilli or lithic clasts in the volcanic debris flow unit in the Carolina slate belt are strongly elongated parallel to $L_{1}$. Likewise, the quartz phenocrysts in the metatrondhjemite unit of the Charlotte belt are elongate parallel to $L_{1}$. In the evenly laminated to massive mudstone and wacke unit of the Carolina slate belt, the $L_{0 \times 1}$ 
intersection lineation has the same orientation as the $L_{1}$ elongation lineation in adjacent stratigraphic units.

The axis of a major $D_{1}$ syncline coincides with the outcrip band of mudstone and wacke that crosses through the southern parts of the Chapin and Little Mountain quadrangles. The $S_{1}$ slaty cleavage dips steeply to the northwest in this region approximately parallel to the axial surface of the $D_{1}$ syncline. The volcanic debris flow unit $\left(\epsilon_{d f}\right)$ which underlies the mudstone and wacke unit outcrops on both flanks of the $D_{1}$ syncline. In the south-central part of the Chapin quadrangle along Wateree Creek, the $D_{1}$ syncline seems to have a relatively broad axial zone in which the primary stratification $\left(S_{0}\right)$ is sub-horizontal for a width of approximately one kilometer. The $D_{1}$ deformation described in the present study area is thought to be synchronous with the $D_{1}$ deformation that has been described elsewhere in the slate and Charlotte belts (Secor and Snoke, 1978; Bourland and Farrar, 1983) and is probably Early to Mid Paleozoic.

In the central and northern parts of the Chapin and Little Mountain quadrangles the $S_{1}$ foliation has been variably folded by a series of mesoscopic and macroscopic flexural folds $\left(D_{2}, F_{2}\right)$. The style and orientation of these later folds is variable from place to place, and more than one distinct sub-episode may be present (Bourland and Farrar, 1980). In most places the axes of mesoscopic $F_{2}$ folds are parallel to the $L_{1}$ elongation lineation, but locally the orientations of $L_{1}$ and $F_{2}$ are widely divergent. The effects of the $D_{2}$ deformation in the present study area resemble the $D_{2}$ deformational effects observed along the southern edge of the Carolina slate belt (Secor and Snoke, 1978) where a Carboniferous age for $D_{2}$ has been demonstrated. Therefore, the $D_{2}$ deformation in the present study area may also be Carboniferous; however, Bourland and Farrar (1980) 
concluded that the later deformational phases in this region predate the emplacement of the $300 \mathrm{~m} . y$. Winnsboro intrusive complex, and in the present. study area the Carboniferous plutonic rocks appear to be undeformed. We conclude that $D_{2}$ occurred in the early Carboniferous prior to $300 \mathrm{~m} . \mathrm{y}$.

\section{III.6 The Wateree Creek Fault}

A late episode of brittle faulting has apparently affected the rocks in the Carolina slate and Charlotte belts. At present, the clearest example of a late brittle fault occurs along Wateree Creek in the central part of the Chapin quadrangle. The Wateree Creek fault extends for about eight kilometers in a north-south direction from near the southern edge of the Chapin quadrangle to a point about 2 kilometers southeast of Peak in the northern part of the quadrangle. The following observations point to the existence of a fault along this zone.

1) There is an apparent discontinuity of the magnetic anomaly pattern along the zone (see Fig. 6).

2) Considerable drag is apparently associated with the fault zone so that $S_{0}$ and $S_{1}$ have anomalous orientations and $L_{1}$ has been rotated into steeply plunging to vertical orientation (Points B, C, and D, Plate I).

3) Fault breccia, both silicified and unsilicified is found in the zone (Points $A$ and $B$, Plate I).

4) Open extension fractures, partly infilled with quartz are associated with the zone (Point B, Plate I).

5) Both stratigraphic contacts and the border between the slate and Charlotte belts appear to be offset by the zone (Plate I). 


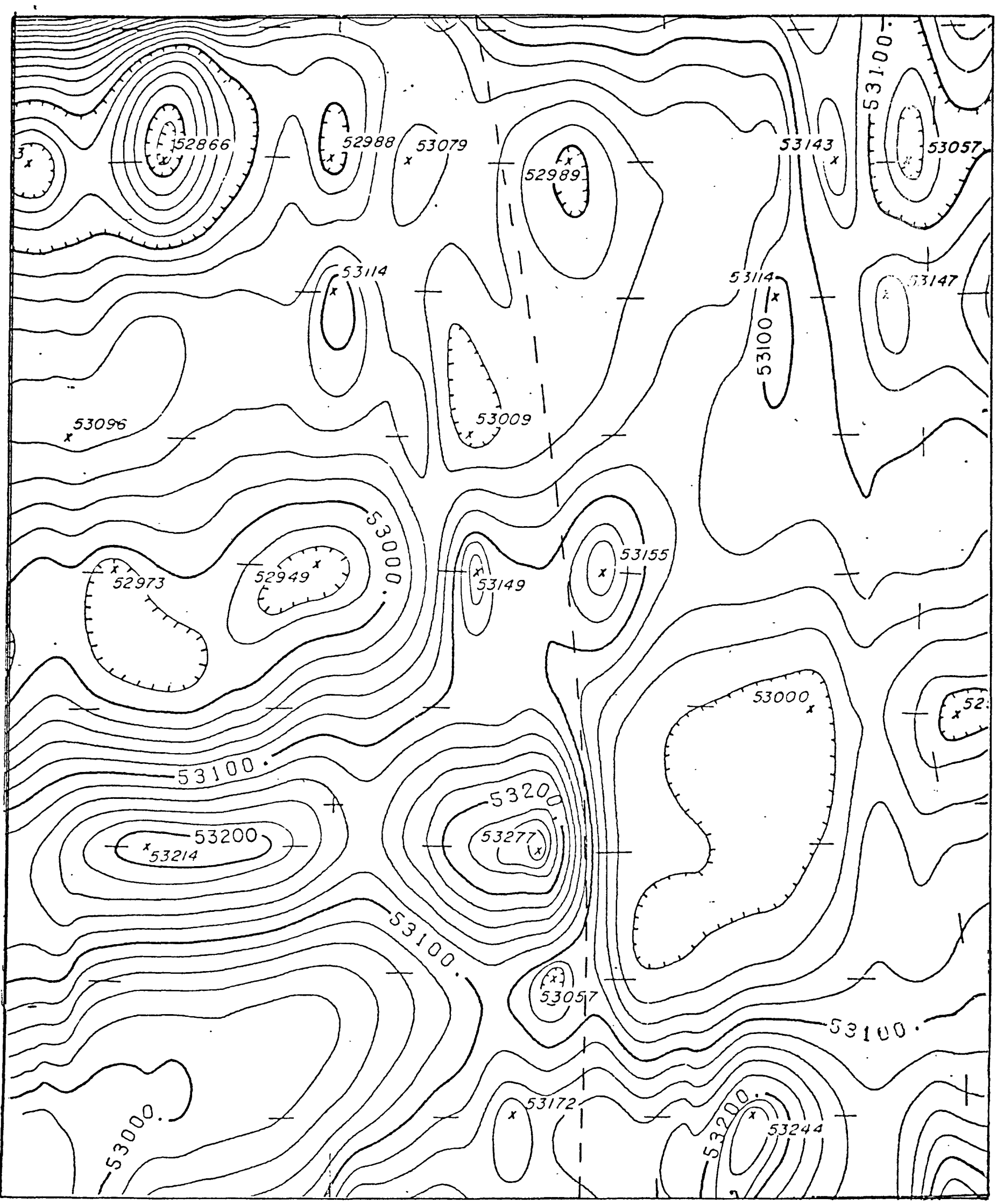

Figure 6. Aeromagnetic map of the Chapin Quadrangle (U.S.G.S., 1978), showing the location of the Wateree Creek fault. 
6) The zone appears to offset older east-west trending silicified breccia zones (Point B, Plate I).

7) The zone also appears to offset a Jurassic (?) diabase dike (P1ate V).

The sense of apparent strike-separation of stratigraphic contacts by the Wateree Creek fault changes from sinistral to dextral in going from north to south along Wateree Creek across the axis of the $D_{1}$ synclinorium. This suggests that the fault has experienced predominately dip-slip displacement and that the east side is down relative to the west side. The observed drag of the $S_{0}$ and $S_{1}$ foliations and the $L_{1}$ lineation are compatible with this inferred movement sense.

Our preliminary observations indicate that both silicified breccia zones of probable Mesozoic age and a Jurassic (?) diabase dike are offset by the Wateree Creek fault. The time of latest movement must therefore be more recent than the Jurassic. In a road cut at location $B$ (Plate $I$ ) it appears that a layer of surficial colluvium is not offset by the fault; however, the age of the colluvium is not known and so no definite upper limit on the time of latest movement has yet been determined.

Location A (Plate I) is an outcrop of fault breccia in a small stream, and is the most northerly control point that we presently have on the Wateree Creek fault. Point $A$ is located approximately 8 kilometers south of Monticello Reservoir. If the Wateree Creek fault is projected to the northwest, it will coincide with the narrow drainage divide between the west side of Lake Monticello and the Broad River. This is the region of most intense seismic activity associated with Lake Monticello, and also a region where fault plane solutions for the earthquake data predict a 
north-south strike for the fault planes (Talwani and others, 1980, p. 134). However the geophysical fault plane solutions suggest that low angle thrusting is the dominant failure mechanism along this zone, whereas our geological observations (Location B, Plate I) indicate that the Wateree Creek fault is steeply dipping to vertical.

In conclusion, it has not yet been demonstrated that there is a connection between the Wateree Creek fault and the seismic activity along the west side of Lake Honticello. However, such a connection is possible, and we are optimistic that our work in this region will ul timately provide the necessary data for deciding if the Wateree Creek fault is one of the controlling boundary conditions for the induced seismicity at Lake Monticello.

\section{III.7 Summers Branch Fault}

Preliminary geologic field data suggests that there is a rorth trending fault along the eastern edge of the Litile llountain quadrangle in the vicinity of Bear Creek and Summers Branch (Plate II). Although this is a region of sparse outcrops, it appears that the stratigraphic contacts are offset. The apparent strike separation of stratigraphic contacts by the Summers Branch fault changes from dextral to sinistral in going from north to south across the axis of the $D_{1}$ synclinorium. This suggests that the displacement of the Summers Branch fault is predominately dip-slip and that the west side is down relative to the east side. Open extension fractures, partly filled with quartz, have been observed at location $E$ (Plate II) near the inferred position of the Summers Branch fault. However, the Summers Branch fault is not evident in the U.S. Geological Survey aeromagnetic maps of the region. The existence of the Summers Branch 
fault is therefore uncertain. We plan to do additional field studies in this region.

\section{MAGNETIC . IUDIES}

Diabase dikes of Jurassic (?) äge, trending N2OW-N30W (DeBoer, 1967) are the youngest rocks in the study area. It is important that the distribution of diabase dikes be established as precisely as possible in order to detect any offsets that may have been produced by Late Mesozoic or Cenozoic faulting. Therefore, we have undertaken to measure several magnetic profiles trending N7OE, across the study area in order to determine the locations of all of the larger diabase dikes.

The first magnetic profile, extending diagonally across the Chapin and Little Mountain quadrangles was completed during the summer of 1980 , and measurements on a second profile, beginning in the Jenkinsville quadrangle, are underway. Undergraduates Chris Jones, Mark Snyder, and Bruce Crawford have been ssigned primary responsibility for measuring the magnetic profiles. The positions of stations along the profiles are determined by traversing with a Brunton compass and non-magnetic cloth tape. A proton-precession magnetometer was used to measure the total strength of the earth's magnetic field at intervals of twenty-five feet along the profile.

Profile I is illustrated on Plates IV and V. In general, the total strength of the earth's magnetic field varies gradually between 53,000 and 53,400 gammas along the length of the profile. In several places, magnetic anomalies having amplitudes of a few hundred gammas and wave lengths of several hundred meters are present. These are interpreted as anomalies 
related to minor stratigraphic variations in the underlying metasedimentary and metavolcanic rocks along the profile. At two places in the Chapin quadrangle, and at three places in the Little Mountain quadrangle, positive anomalies are encountered which have amplitudes of 700-1600 gammas and wave lengths of 50-200 meters (see Plates IV and V). These are interpreted as diabase dikes, and in most cases this interpretation has been confirmed by finding diabase on strike with the profile anomalies.

During the last few months our attention has been focused on the diabase dike in the Chapin quadrangle which intersects the Hateree Creek fault in the region northwest of White Rock (Plate IV). It is important to establish the relative ages of the fault and dike in order to determine if post-Jurassic (?) displacement has occurred on the wateree Creek fault. Therefore we have undertaken to measure several short magnetic profiles in this region. This work is presently in progress. Preliminary results si'ggest that the dike on the east side of the fault is not on strike wi in the dike on the west side. The dike may therefore be offset by the Wateree Creek fault. However, these relationships could also be explained by an intrusive en-echelon offset of the dike or by the curvature of the dike to a different orientation in the anomalously stressed region near the fault. Hopefully, detailed magnetic studies will enable us to discriminate between these various hypotheses.

In addition to the field-magnetometer studies described above, we plan to conduct paleomagnetic studies of the diabase dikes as an aid in determining their age and in order to determine if reversely magnetized dikes occur that would be useful in geological correlation. These paleomagnetic studies will be conducted by graduate student Bill Smith under the direction of Tom Doley. 


\section{FRACTURE STUDIES}

It is possible that anisotropy related to sets of joint fractures or to metamorphic foliation is one of the important controlling boundary conditions on the seismic activity at Lake Monticello. Measurements on the orientation of metamorphic foliation are being made in conjunction with the field mapping studies that are currently in progress (Plates I, II, III). In order to determine if there are systematically oriented joint sets in the region, we have undertaken joint orientation studies at numerous outcrops where there is sufficient exposure to obtain a statistically valid sampling of the joint pattern. Our original plan was to measure two hundred joints at each of forty locations of extensive outcrop in the study area. During the summer of 1980 we found that it was difficult to obtain 200 measurements at many of the places where joint studies were undertaken. We therefore modified our plan so that approximately 100 measurements would be taken at each of 80 different stations. Where possible the following procedure was used in obtaining the joint measurements: A circular area of diameter two meters was laid out on the surface of the outcrop. All joint fractures that could be seen in the volume of rock inside the circle were measured. Once measured, a joint was marked with chalk to insure that it would not be inadvertently remeasured. Where a joint fracture obviously consisted of several enechelon segments, each major segment was measured. Regularly curved joints were measured by assuming an average planar orientation. Where a joint curves from one planar orientation to another, measurements were taken on both planes. When possible, the length of the joint fracture, parallel to its strike was also measured. However, roughly half of the 
observed joint fractures extended beyond the exposed limits of the outcrop, so we can place no. upper limit on the possible lengths of the joint fractures. During the summer of 1980 graduate student Sarah Logan measured approximately 4200 joints at 39 different locations in the study area. Each set of measurements was punched on cards, and a lower-hemisphere, equal-area stereonet contour diagram was computer plotted for each locality. These contour diagrams for each location are reproduced in Plates VI, VII, VIII and IX. Our observations on the character of the joint fractures in the study area are summarized in the following list:

1) In most places a few characteristic orientations or "sets" seem to predominate in the joint pattern, al though there may also be many fractures that do not obviously belong to any of the sets.

2) Within a given outcrop, the sets seem to have consistent orientations from one place to another, although there may be a large variation in the relative intensity of the sets (see locations 1234 and 1245 in the northern part of the Chapin quadrangle - Plate VI).

3) The individual joint fractures are usually 5-100 cm. long in a direction parallel to strike, although a few joints are much longer than this, extending beyond the limits of exposure.

4) Most of the joints are steeply dipping to vertical, although a few horizontal to gently dipping joints can usually be observed at most locations.

5) The intensity of jointing in the homogeneous postkinematic igneous rocks is much less than in the heterogeneous metamorphic rocks. 
6) Only a small proportion of the joints have mineral infillings of quartz or quartz-feldspar. Zeolite infillings were not observed, al though we expect that any zeolite infillings would have been removed by weathering from the surficial outcrops examined in this study.

7) There appears to be no regional consistency to the orientations and intensities of the major joint sets (compare stereonet patterns in Plates VI, VII, VIII, and IX).

The above studies have indicated that in most places in the area the rocks are highly fractured, and in addition at most locations a strong $S_{1}$ metamorphic foliation is present. However, there appears to be little regional consistency to the orientation of the major joint sets, and as well, the $S_{1}$ foliation has been variably refolded to a variety of orientations by one or more Mid to Late Paleozoic deformation episodes. Based on this preliminary information, it is suggested that the jointing and metamorphic foliation may exert a major influence in the local small-sc. le failures related to the induced seismic activity, but that the lack of regional consistency in their orientations makes it unlikely that they would be the controlling influence leading to major seismic events.

\section{SUMMARY DISCUSSION}

In the present study, it is extremely important to determine if there are major through-going brittle faults in the rocks around Monticello Reservoir. Our field studies suggest that there is a brittle fault following the course of Wateree Creek in the Chapin quadrangle (herein called the Wateree Creek fault). The Wateree Creek fault strikes about 
$\mathrm{N} 5^{\circ} \mathrm{W}$ and if projected to the north will coincide with the drainage divide between Lake Monticello and the Broad River. At present the most northerly point where definite indications of faulting have been found is locaced about $8 \mathrm{~km}$. south of Lake Monticello. During the next several months we plan to focus our efforts toward a more thorough documentation of the Wateree Creek fautt, and toward determining its northern extent.

It is strongly emphasized here that this is the first six-monthi technical report of a project that will last for two years. All of the scientific conclusions presented here are tentative, and all could change as a result of further work. 


\section{REFERENCES CITED}

Black, W. W., 1978. Chemical characteristics and Rb/Sr ages of metavolcanics from the Carolina slate belt near Chapel Hill, N.C.: Geological Society of America Abstracts wi th Programs, v. 10, no. 4, p. $162-163$.

Black, W. W., and Fullagar, P. D., 1976. Avalonian ages of metavolcanics and plutons of the Carolina slate belt near Chapel Hill, N.C. (abs.): Geological Society of America Abstracts with Programs, v. 8, no. 2, p. 136 .

Bourland, W. C., and Farrar, S., 1980. Tectogenes is of the rocks surrounding the Winnsboro intrusive complex: South Carolina Geology, v. 24, no. 1, p. 1-18.

Briggs, D. F., Gilbert, M. C., and Glover, Lynn, III, 1978. Petrology and regional significance of the Roxboro metagranite, North Carolina: Geological Society of America Bulletin, v. 89, no. 4, p. 511-521.

Brown, H. S., and Gilbert, N. J., 1977. Geologic history of a fault system in the Charlotte belt, northern South Carolina (abs.): Geological Society of America Abstracts with Programs: v. 9, no. 2, p. $122-123$.

Butler, J. R., 1977. Comments on zeolite formation in the Carolina Piedmont (abs.): Geological Society of America Abstracts with Proarams, v. 9, no. 2, p. 124-125.

Butler, , R., and Fullagar, P. D., 1975. Lilesville and Pageland plutons and associated meta-rhyolites, eastern Carolina slate belt (abs.): Geological Society of America Abstracts with Programs, v. 7, no. 4, p. 475 .

Butler, J. R., and Fullagar, P. D., 1978. Petrochemical and geochronological studies of plutonic rocks in the southern Appalachians: III. Leucocratic adamellites of the Charlotte belt near Salisbury, North Carolina: Geological Society of America Bulletin, v. 89, no. 3, p. 460-466.

Butler, J. R., and Ragland, P. C., 1969. Petrology and chemistry of metaigneous rocks in the Albemarle area, North Carolina slate belt: American Journal of Science, v. 267, no. 6, p. 700-726.

Carpenter, R. H., 1976. General geology of the Carolina slate belt along the Georgia-South Carolina border; in Chowns, T. H., compiler, Stratigraphy, structure and seismicity in slate belt rocks along the Savannah River: Georgia Geological Survey, Guidebook 16, p. 9-12. 
Carpenter, R. H., Odom, A. L., and Hartley, M. E., III, 1978. Geochronology of the southern portion of the slate belt (abs.): Geological Society of America Abs tracts wi th Programs, v. 10, no. 4, p. 164.

Clark, W. D., 1969, Geology of the Whi terock-Chapin area, South Carolina: Columbia, South Carolina, University of South Carolina Mas ters Thesis.

Cloud, P., Wright, J. E., and Glover, L., III, 1976. Traces of animal life from 620-million-year-old rocks in North Carolina: American Scientist, v. 64, no. 4, p. 396-406.

Conley, J. F., and Drummond, K. M., 1964. UT tramyloni te zones in the western Carolinas: Southeas tern Geology, v. 6, no. 4, p. 201-211.

Cook, F. A., Albaugh, D. S., Broinn, L. D., Kaufman, S., Oliver, J. E., and Hatcher, R. D., Jr., 1979. Thin-skinned tectonics in the crystalline southern Appalachians; COCORP seismic-reflection profiling of the BTue Ridge and Piedmont: Geology, v. 7, no. 12, p. 563-567.

Dames and Moore, 1974. Supplemental geologic investigation, Virgil C. Summer Nuclear Station- unit one, for South Carolina Electric and Gas Company, $62 \mathrm{p}$.

Dames and Moore, 1975. Supplemental geologic investigation, Virgil C. Summer Nuclear Station - unit one, Addendum I, II, III, IV, for South Carolina Electric and Gas Company.

Daniels, D. L., 1974. Geologic interpretation of gecphysical maps, central Savannah River area, South Carolina and Georgia: U.S. Goological Survey, Geophysical Inves tigations Map GP-893, 1:250,00L, 3 sheets, text.

Fullagar, P. D., 1971. Age and origin of plutonic intrusions in the Piedmont of the southeastern Appalachians: Geological Society of America Bulletin, v. 82, no. 10, p. 2845-2862.

Fullagar, P. D., and Butler, J. R., 1979. 325 to 265 m.y.-old granitic plutons in the Piedmont of the southeastern Appalachians: American Journal of Science, v. 279, no. 2, p. 161-185.

Gilbert, N. J., and Schaeffer, M. F., 1979. A sys tem of wrench faul ting in the Charlotte belt, York County, South Carolina: Geological Society of America Abs tracts wi th Programs, v. 11, no. 4, p. 180.

Glover, L., III, and Sinha, A. K., 1973. The Virgilina deformation, a la te Precambrian to early Cambrian (?) orogenic event in the central Piedmont of Virginia and North Carolina: American Journal of Science, v. 273-A, p. 234-251. 
Harris, L. D., and Bayer, K. C., 1979. Sequential development of the Appalachian orogen above a master decollement - A hypothesis: Geology, v. 7, no. 12, p. 568-572.

Hills, F. A., and Butler, J. R., 1969. Rubidium-strontium dates for some rhyolites from the Carolina slate belt of the North Carolina Piedmont: Geological Society of America Abstracts for 1968, Special Paper 121, p. 445 .

Howel1, D. E., and Pirkle, W. A., 1976. Geologic section across the Modoc fault zone, Modoc, South Carolina; in Chowns, T. M., compiler, Stratigraphy, structure, and seismicity in slate belt rocks along the Savannah River: Georgia Geological Survey, Guidebook 16, p. 16-20.

Kish, S. A., and Fullagar, P. D., 1978. Summary of geochronological data from late Paleozoic plutons from high grade metamorphic belts of the eastern Piedmont of North Carolina, South Carolina, and Virginia; in Snoke, A. W., editor, Geological investigations of the eastern Piedmont, southern Appalachians: Carolina Geological Society Field Trip Guidebook 1978, South Carolina Geological Survey, p. 61-64.

Maher, H. D., 1978. Stratigraphy and structure of the Belair and Kiokee belts, near Augusta, Georgia; in Snoke, A. W., editor, Geological investigations of the eastern Piedmont, southern Appalachians: Carolina Geological Society Field Trip Guidebook for 1978, South Carolina Geological Survey, p. 47-54.

Maher, H. D., Palmer, A. R., Secor, D. T., Jr., and Snoke, A. W., 1n 30 in press. A new trilobite locality in the Piedmont of South Carolina: Geology.

O'Connor, B. J., and Prowel1, D. C., 1976. The geology of the Belair fault zone and basement rocks of the Augusta, Georgia area; in Chowns, T. M., compiler, Stratigraphy, structure, and seismicity in slate belt rocks along the Savannah River: Georgia Geological Survey, Guidebook 16, p. 21-32.

Pirkle, W. A., 1977. Geology of the Red Hill quadrangle, Edgefield County, South Carolina: Geologic Notes, Division of Geology, South Carolina Sta te Development Board, v. 21, p. 75-84.

Pirkle, W. A., 1978. Preliminary report on the geology of the Parksville quadrangle, McCormick and Edgefield counties, South Carolina: Geologic Notes, South Carolina Geological Survey, South Carolina State Development Board, v. 22, p. 95-104.

Privett, D. R., 1973a. Paragenes is of an unusual hydrothermal zeolite assemblage in a diorite-granite contact zone, Woodleaf, Rowan County, North Carolina: Southeastern Geology, v. 15, no. 2, p. 105-118.

Privett, D. R., 1973b. Laumontization near the northern margin of the Liberty Hill batholith, southern Chester County, South Carolina: South Carolina Geological Survey, Geologic Notes, v. 17, no. 3, p. 49-54. 
Privett, D. R., 1974a. Widespread laumontization in the central Piedmont of North Carolina and southern Virginia (abs.): Geological Society of America Abstracts with Programs, v. 6, no. 4, p. 389-390.

Privett, D. R., 1974b. Laumontization in Kings Mountain belt rocks, Cherokee County, South Carolina: South Carolina Geological Survey, Geologic Notes, v. 18, no. 2, p. 31-35.

Privett, D. R., 1977. Widespread zeolitization in the central Charlotte belt, north-central York County, South Carolina (abs.): Geological Society of America Abstracts wi th Programs, v. 9, no. 2, p. 176.

Prowel1, D. C., and O'Connor, B. J., 1978. Belair fault zone: Evidence of Tertiary fault displacement in eastern Georgia: Geology, v. 6 , no. 11, p. 681-684.

Secor, D. T., Jr., and Wagener, H. D., 1968. Stratigraphy, structure, and petrology of the Piedmont in central South Carolina: South Carolina Geological Survey, Geologic Notes, v. 12, no. 4, p. 67-84.

Secor, D. T., Jr., and Snoke, A. W., 1978. Stratigraphy, structure and plutonism in the central South Carolina Piedmont; in Snoke, A. W., editor, Geological investigations of the eastern Piedmont, southern Appalachians: Carolina Geological Society Field Trip Guidebook for 1978, South Carolina Geological Survey, p. 65-123.

Seiders, V. M., and Wright, J. E., 1977. Geology of the Carolina volcanic slate belt in the Asheboro, North Carolina area; in Burt, E. R., editor, Field guides for Geological Society of Ame: ica, Southeas tern Section Meeting, Winston-Salem, North Carolina: North Carolina Department of Natural and Economic Resources, Division of Earth Resources, p. 1-34.

Snipes, D. S., Davis, M. W., and Manoogian, P. R., 1979. Cross Plains fault in the Piedmont of northwestern South Carolina (abs.): Geological Society of America Abstracts with Programs, v. 11, no. 4, p. 213.

Snoke, A. W., Secor, D. T., Bramlett, K. W., and Prowell, D: C., 1980. Geology of the eastern Piedmont fault sys tem in South Carolina and eastern Georgia; in Excursions in southeastern geology, Guidebook for the 1980 Annual Meeting of the Geological Society of America, Washington, D.C., American Geological Institute, v. 1, p. 59-100.

St. Jean, Joseph, 1973. A new Cambrian trilobite from the Piedmont of North Carolina: American Journal of Science, v. 273-A, p. 196-216.

Talwani, P., 1979. Induced seismicity and earthquake prediction studies in South Carolina: Eighth Technical Report to the U.S. Geological Survey, Contract no. 14-08-0001-16, 36 p. 
Talwani, P., Stevenson, D., Sauber, J., Rastogi, B. K., Drew, A., Chiang, J., and Amick, D., 1978. Seismicity studies at Lake Jocassee, Lake Keowee, and Monticello Reservoir, South Carolina (October 1977March 1978): Seventh Technical Report to the U.S. Geological Survey, Contract no. 14-08-0001-14553, 151 p.

Talwani, P., Rastogi, B. K., and Stevenson, D., 1980. Induced seismicity and earthquake prediction studies in South Carolina: Tenth Technical Report to the U.S. Geological Survey, Contract no. 14-08-0001-17670, $212 \mathrm{p}$.

Wagener, H. D., 1970. Geology of the southern two-thirds of the Winnsboro 15-minute quadrangle, South Carolina: South Carolina Geological Survey, MS-17, $34 \mathrm{p}$.

Wagener, H. D., 1977a. The granitic stone resources of South Carolina: South Carolina Geological Survey, Mineral Resources Series 5, 65 p.

Wagener, H. D., 1977b. Zeolites as indicators of time of latest movement on Piedmont faults: the Virgil C. Summer Nuclear Station (abs.):

- Geological Society of America Abstracts with Programs, v. 9, no. 2, p. 192-193.

Weisenfluh, G. A., and Snoke, A. W., 1978. An epizonal trondhjemitequartz keratophyre complex near Calhoun Falls, South Carolina: South Carolina Geological Survey, Geologic Notes, v. 22, no. 2, p. 48-73.

Whitney, J. A., Paris, T. A., Carpenter, R. H., and Hartley, M. E., III, 1978. Volcanic volution of the southern slate belt of Georgia and South Carolina: A primitive oceanic island arc: Journal of Geology, v. 86 , no. 2 , p. 173-192.

Williams, H., 1978. Tectonic lithofacies map of the Appalachian orogen: St. Johns, Newfoundland, Canada, Memorial University of Newfoundland, $1: 1,000,000$.

Wright, J. E., and Seiders, V. M., 1977. U-Pb dating of zircons from the Carolina volcanic slate belt, central North Carolina: Geological Society of America Abstracts with Programs, v. 9, p. 197-198. 